\title{
Effects of intra articular tramadol on articular cartilage and synovium of rats
}

\author{
Eklem içine verilen tramadolün eklem kartilaj ve sinovyuma etkileri \\ Musa Kola ${ }^{1}$, Sennur Uzun², Naciye Dilara Zeybek ${ }^{3}$, Fatma Sarıcaoğlu², Seda Banu Akıncı², Ülkü Aypar², Esin Asan³
}

\begin{abstract}
Objective: To investigate the effects of intra articular tramadol injection on articular cartilage and synovium in rat knee joint.

Methods: After Animal Ethical Committee approval, a total of 20 Sprague-Dawley rats were used and divided into 4 groups. Each group was composed of 5 rats. $0.2 \mathrm{ml}$ of tramadol $\mathrm{HCl}$ was injected into the right knee joints and left knee joints of all the rats were considered as control. Control side joints received saline injection. Rats were sacrificed with ketamin on 1st, 7th, 14th and 21st days and knee joints were removed. Obtained tissue samples were decalcified and were dyed with Hematoxylin-eosin and Masson's trichrome stain and examined by light microscopy for the presence of inflammation in periarticular area and synovia.
\end{abstract}

Results: Congestion of synovial veins and perivascular cell infiltration were observed in tramadol group on days 1 and $7(P<0.05)$. The inflammation process was replaced by fibrosis on day 14 and fibrosis was significantly decreased on day 21.

Conclusion: Intra articular tramadol should be used cautiously, keeping in mind that it may cause synovial inflammation in early phases and fibrosis in late phases. $J$ Clin Exp Invest 2015; 6 (4): 337-342

Key words: Analgesics, opioid, tramadol, rat, hyaline cartilage, arthroscopy

\section{INTRODUCTION}

Arthroscopic procedures for diagnosis and treatment is quite often amongst outpatient surgeries. Effective postoperative analgesia with lowest side effect is very important for patient comfort, early patient mobilization and discharge. New techniques are being investigated to provide fast recovery after arthroscopic surgery. Opioids are part of anesthetic

\section{ÖZET}

Amaç: Fare diz eklemine yapılan tramadolün kıkırdak ve sinovyuma etkilerinin incelenmesi

Yöntemler: Hayvan Etik Komite onayı alındıktan sonra, toplam 20 Sprague-Dawley fare dört eşit gruba ayrıldı. $0.2 \mathrm{ml}$ tramadol $\mathrm{HCl}$ hayvanların sağ diz eklemine enjekte edildi ve sol dizler kontrol olarak kabul edildi. Kontrol tarafındaki eklemlere serum fizyolojik enjeksiyonu yapıldı. Birinci, 7., 14. ve 21. Günlerde ölümcül doz ketamin ile hayvanlar sakrifiye edilerek eklemler histopatolojik inceleme için çıkarıldı. Elde edilen doku örnekleri dekalsifiye edildikten sonra Hematoxilen-Eosin ve Masson's trichrome boyası ile boyandı, periartikülar ve sinovyum çevresinde inflamasyon olup olmadığını araştırmak için ışık mikroskopu ile incelendi.

Bulgular: 1. ve 7. gün tramadol grubunda sinovyal damarlarda genişleme ve perivasküler hücre infiltrasyonu gözlendi $(p<0.05)$. 14. günde inflamasyon yerini fibrozise bıraktı ve 21. gün önemli derecede azaldı.

Sonuç: Eklem içi tramadol kullanırken, erken dönemde eklemde inflamasyona, geç dönemde fibrozise neden olabileceği akılda bulundurularak dikkatli olunmalıdır.

Anahtar kelimeler: Analjezik, opiod, tramadol, fare, hyaline kıkırdak, artroskopi

technique and provide effective analgesia after arthroscopy [1] but fears about addiction and respiratory and cardiovascular depression can result in a reluctance of enough dose leading to insufficient analgesia.

Intra articular drug administration for preemptive and postoperative analgesia is commonly used in various arthroscopic or orthopedic procedures. NSAIDs, bupivacaine and morphine are most com-

\footnotetext{
${ }^{1}$ Bursa Devlet Hastanesi Anesteziyoloji ve Reanimasyon, Bursa, Türkiye

${ }^{2}$ Hacettepe Üniversitesi Tıp Fakültesi Anesteziyoloji ve Reanimasyon, Ankara, Türkiye ${ }^{3}$ Hacettepe Üniversitesi Histoloji ve Embroyoloji, Ankara, Türkiye
}

Correspondence: Şennur Uzun,

Hacettepe Üniversitesi Tıp Fakültesi Anesteziyoloji ve Reanimasyon Ankara, Türkiye Email: sennuruzun1@gmail.com 
monly used. There are many studies investigating the analgesic effects of these agents [2-9], but there are only few studies investigating their histopathologic effects on the cartilage and synovium $[10,11]$. Histopathologic effects caused by local administration of a drug on application site is essential. In vitro studies have shown that different NSAIDs have different effects on cartilage metabolism and proteoglycan synthesis [11-13]

Tramadol is an antinociceptive drug distinguished by its mechanism of action, it acts as an analgesic as well by the agonistic action on $\mu$-opioid receptors localized in the central and peripheral nervous system as by a nonopioid mechanism $[14,15]$. Beside the opioid effects, it inhibits norepinephrine and serotonin reuptake. Some previous studies with intraarticular tramadol use in patients with postoperative pain indicated its significantly weaker analgesic action in comparison with morphine [16]. The above-described action was probably to a greater extent dependent on the opioid component, while the non-opioid component was less significant. Although there are many studies investigating its analgesic effect, there are few studies looking for its histopathologic effects $[17,18]$.

The aim of this study was to investigate whether intra articular tramadol injection was harmful on articular cartilage and synovium in rat knee joint.

\section{METHODS}

This prospective study was carried out after the approval of Animal Ethical Research committee, with the cooperation of the departments of anesthesiology and Reanimation, histology-embryology and animal research laboratory in Hacettepe University Faculty of Medicine between March 2012-June 2012. Pubmed search was used to find prior related research in a paragraph.

\section{Animals}

A total of 20 male Sprague-Dawley rats weighted between 270-320 gr. breeded and cared in Animal Research Laboratory in the same conditions. During the experiment rats were kept in cages containing 5 rats, fed with standard laboratory nutrients. Fluids or foods were not restricted. All experiments were carried out according to the National Institutes of Health Guide for the Care and Use of Laboratory Animals and recommendations of the IASP [19].

Each rat's right knee joints were set as study group and left knee joints were set as control group. Rats were anesthetized with $0.4 \mathrm{mg} / \mathrm{kg}$ intraperi- toneal midazolam (Demizolam, İstanbul, Turkey). Each rat was injected with $0.2 \mathrm{ml}$ of standard tramadol solution (Contramal, Berlin, Germany) selected on the basis of pilot studies, in the right knee joints and $0.2 \mathrm{ml}$ of $0.9 \%$ saline in the left knee joints in aseptic conditions. Intra articular space can take up to $0.2 \mathrm{ml}$ in rats. $10 \mathrm{mg}$ of tramadol which corresponds to a volume of the appropriate dose was used. After the injection, the animals were awakened and put to separate cages containing 5 rats in each.

Following intra articular injection, rats on assigned groups were sacrificed by $30 \mathrm{mg} \cdot \mathrm{kg}-1$ lethal dose of intraperitoneal ketamin (Ketalar, İstanbul, Turkey) on days $1,7,14$ and 21. After appropriate field clearance arthrotomy was performed on both knee joints by medial parapatellar incision. Patella was overturned laterally, anterior articular surface of distal femur was opened, incision was extended distally and anterior surface of tibia was reached. All soft tissue was removed from femur and tibia and knee joints were extracted as a whole block. After examining for gross signs of hematoma, samples were labeled as right (R), left (L), saline (SF), tramadol $\mathrm{HCl}(\mathrm{T})$ and labeled as group 1, 2, 3, 4 .

Group 1 was composed of 5 rats sacrificed on day 1 , after the injection. 10 samples were taken including 5 for study group (T1) and 5 for control group (SF1) samples.

Group 2 was composed of 5 rats sacrificed on day 7 , after the intra articular injection. 10 samples were taken including 5 for study group (T2) and 5 for control group (SF2) samples.

Group 3 was composed of 5 rats sacrificed on day 14 , after the intra articular injection. 10 samples were taken including 5 for study group (T3) and 5 for control group (SF3) samples.

Group 4 was composed of 5 rats sacrificed on day 21, after the intra articular injection. 10 samples were taken including 5 for study group (T4) and 5 for control group (SF4) samples.

Tissue samples were kept in room temperature for 2 weeks in $10 \%$ buffered formalin solution followed by 4 weeks of decalcification in De Castro solution. During the decalcification process tissues were checked in every 3 days and the solution was renewed. Decalcified tissues were placed in tapes, fixated with $10 \%$ buffered formalin and taken into light microscopy tissue tracking device.

Tissue samples were examined by two histologists (blinded to study groups) by Leica DM6000B 
(Wetzlar-Germany) microscope attached with DC490 digital camera (Leica, Wetzlar-Germany) and photographed.

Joint, periarticular area and synovium were examined for signs of inflammation. Major criteria evaluated by comparing the control and tramadol groups under light microscopy were; changes

a) Articular cartilage structure and observed

b) Synovial structure and observed changes

c) Inflammatory responses due to both mechanical trauma and intra articular drug administration.

The presence of inflammation in the articular and periarticular regions and synovium were evaluated by two histologists who were blinded to the treatment. Inflammatory changes in the joints were graded according to a five-point scale. Grade 1- no inflammation, Grade 2- minimal inflammation: mild congestion and edema, Grade 3- mild inflammation: erosion of joint surface, congestion and edema, small number of neutrophils), Grade 4- moderate inflammation: neutrophils and macrophages, synoviocyte hyperplasia, and Grade 5- severe inflammation: neutrophils and macrophages, synoviocyte hyperplasia, fibrin exudation [9].

\section{Statistical Analysis}

SPSS 12.0 (Statistical Package for Social Sciences, SPSS Inc, Chicago, IL, United States) was used for statistical analysis of the results. A power analysis was performed, according to the presence of inflammation in synovium with 0.05 significance and 5 rats for each group was calculated. Mann Whitney $\mathrm{U}$ test was used for the comparison of the inflammatory changes between groups. Results were given as median (minimum-maximum). Chi-square tests was used to compare inflammation degree. The Fischer Exact test was used to compare differences between the experimental and control groups at 1st, 2 nd, 7th, 14th and 21th days. $P<0.05$ was considered as statistically significant.

\section{RESULTS}

Non of the knee joints showed gross signs of hematoma at the time of removal.

\section{$1^{\text {st }}$ day histopathologic examination}

Articular cartilage structures in saline group revealed normal histologic pattern and no inflammation was seen in synovium of control group. Articular cartilages were intact and normal structure was preserved in tramadol group. Interstitial cartilage proliferation was observed on upper surface cells of the articular cartilage. Subsynovial adipose tissue was observed to be quite well developed. Minimal vascular congestion and cell infiltration in perivascular area were seen in synovium of tramadol group (Table 1).

Table 1. Grading of histopathologic inflammatory changes of $0.9 \%$ saline or tramadol injected rat knee joints

\begin{tabular}{|c|c|c|c|c|c|c|c|c|c|}
\hline \multirow[b]{2}{*}{ Grade } & \multicolumn{2}{|c|}{$1^{\text {st }}$ Day } & \multicolumn{2}{|c|}{$7^{\text {th }}$ Day } & \multicolumn{2}{|c|}{$14^{\text {th }}$ Day } & \multicolumn{2}{|c|}{$21^{\text {st }}$ Day } & \multirow[b]{2}{*}{$p$} \\
\hline & $\begin{array}{c}\text { Saline } \\
n=5\end{array}$ & $\begin{array}{c}\text { Tramadol } \\
n=5\end{array}$ & $\begin{array}{c}\text { Saline } \\
n=5\end{array}$ & $\begin{array}{c}\text { Tramadol } \\
n=5\end{array}$ & $\begin{array}{c}\text { Saline } \\
n=5\end{array}$ & $\begin{array}{c}\text { Tramadol } \\
n=5\end{array}$ & $\begin{array}{c}\text { Saline } \\
n=5\end{array}$ & $\begin{array}{c}\text { Tramadol } \\
n=5\end{array}$ & \\
\hline 0 & 4 & 1 & 4 & 2 & 5 & 4 & 5 & 4 & 0.056 \\
\hline 1 & 1 & 0 & 1 & 0 & 0 & 1 & 0 & 0 & 0.222 \\
\hline 2 & 0 & 4 & 0 & 3 & 0 & 0 & 0 & 1 & 0.024 \\
\hline 3 & 0 & 0 & 0 & 0 & 0 & 0 & 0 & 0 & 0.690 \\
\hline 4 & 0 & 0 & 0 & 0 & 0 & 0 & 0 & 0 & 0.690 \\
\hline
\end{tabular}

\section{$7^{\text {th }}$ day histopathologic examination}

No changes in articular cartilage or synovia had been observed in control group. Articular cartilages were normal, but chondrocyte proliferation was significant in tramadol group. It was observed that development was accelerated due to irritation in cortical bone and bone marrow epiphysis plate where vascularization was increased. Synovial membrane thickness was normal and synoviocytes were in normal structure. Vascular congestion and cell infiltration were reduced but still could be observed in synovium in tramadol group.

\section{$14^{\text {th }}$ day histopathologic examination}

Normal histologic pattern was observed in articular cartilage and synovium and there wasn't any cell 
infiltration in synovium of control group. In tramadol group, synovium was rich in fibroblasts, the synovi- um connective tissue was more fibrotic and minimal cell infiltration was seen (Figure 1).
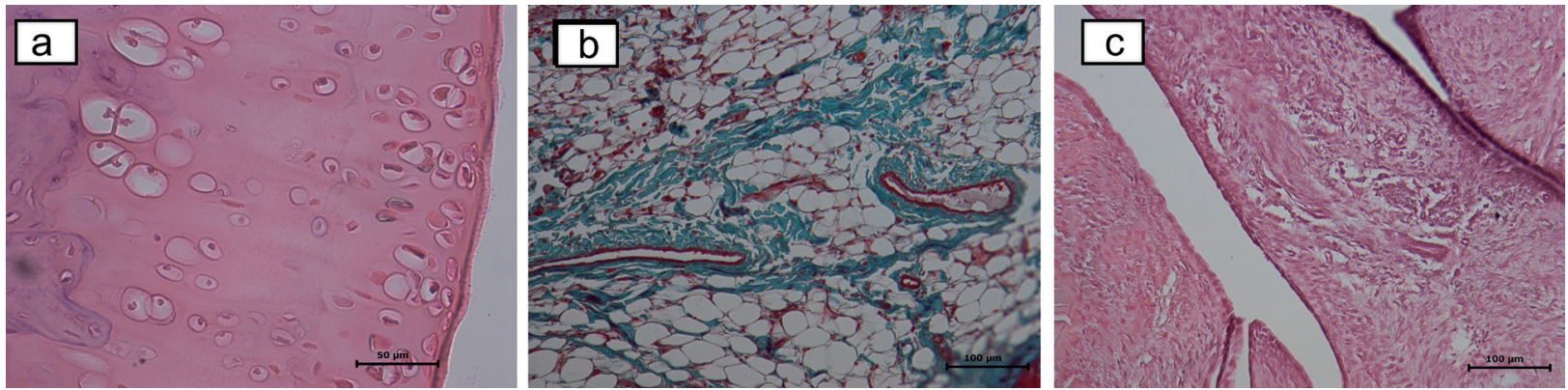

Figure 1. 1a. Interstitial proliferation in articular chondrocyte in tramadol group on day 1 (hematoxilen-eosin dye); 1 b. Cell infiltration around the vessels in tramadol group on day 1, (hematoxilen-eosin dye); 1c. Fibroblast rich synovium in tramadol group on day 14 (hematoxilen-eosin dye)

\section{$21^{\text {st }}$ day histopathologic examination}

Articular cartilage and synovium kept their normal structure in control group. In tramadol group, there was significant chondrocyte proliferation at articular cartilage and volume increase. In spite of the expanded veins filled with erythrocytes there was no cell infiltration determined in synovium. Fibrotic changes in synovial connective tissue was decreased significantly and synovium was observed similar to its normal structure.

It was found that inflammation degrees of rat knee joints in tramadol group was higher compared to saline as shown in Table $2(p=0.04)$.

Table 2. Comparison of saline and tramadol groups according to inflammation degrees

\begin{tabular}{ccccc}
\hline $\begin{array}{l}\text { Inflammation } \\
\text { degree }\end{array}$ & Saline & Tramadol & Total & $\mathbf{p}$ \\
\hline 0 & 18 & 11 & 29 & 0.06 \\
1 & 2 & 1 & 3 & 0.07 \\
2 & 0 & 8 & 8 & 0.04 \\
\hline Total & 20 & 20 & 40 & \\
\hline
\end{tabular}

\section{DISCUSSION}

In this study, we investigated the effect of tramadol on cartilage and synovium of rat joints. We applied tramadol to knee joints of rats. The cartilage tissue was rich in fibroblasts on day 14, in tramadol group, the synovium connective tissue was more fibrotic and minimal cell infiltration was seen. We found statistically higher degree of inflammation at the end of day 1 .
NSAIDs have effects on joint cartilage even when given systemically, due to their ability to disrupt chondrocyte metabolism and to inhibit proteoglycan synthesis [13]. These effects may be more pronounced in patients with osteoarthritis. NSAIDs are the most widely studied agents for the effects of intra articular administration. Fujii et al. [12] studied chondrocyte culture and David et al. [20] investigated osteoarthritic cartilages obtained from humans. They showed different effects of NSAIDs on cartilage metabolism and proteoglycan synthesis in vitro. Romsing et al. [14] applied NSAIDs locally and showed that many NSAIDs inhibits proteoglycan synthesis and disturbs chondrocyte metabolism when administered systemically.

In another study, intra articular tenoxicam was administered to 50 rats' knee joints and pathological changes were examined on days 1, 2, 7, 14 and 21. Control group showed no pathological changes whereas all of the samples which were applied tenoxicam have tissue loss and edema on days 1 and 2. There were no pathological changes in both groups on days 7, 14 and 21 [21]. The design and day 1 results of this study was similar to our results.

There is only one study which investigates the histopathologic effects of intra articular drug use in humans. In the study of Balabanova et al. [22], they injected $8 \mathrm{mg}$ of intra articular lornoxicam once a week for 3 weeks to 58 patients with rheumatoid arthritis and joints were evaluated by ultrasonography for possible changes. Ultrasonographic analysis showed thinning of synovial membrane and reduction of synovial fluid in joint space. This study showed that intra articular lornoxicam injection does not cause articular damage but it increases 
pre-existing inflammation process. All of these studies proves that different drugs can cause different histopathologic effects on joints when administered intra-articularly. In our study, we found that intra articular tramadol injection causes inflammation on rat knee joints. In particular, second degree inflammation levels (moderate inflammation, erosion on joint surface, congestion and edema, few neutrophils) was found statistically significant on day 1 and maintained to a certain level on the other days. We observed that this inflammation process was diminished by day 14 and fibrotic changes seen on day 14 were significantly decreased by day 21 . Garlicki et al. [17] studied a possible antinociceptive effect of tramadol administered intraarticularly, both preemptively and after inflammation, in the model of knee joint model. They demonstrated that it can diminish nociceptive process acting at the level of peripferal nervous system, suppressing peripheral sensitization. Although they showed the peripheral antinociceptive effect of tramadol in different doses, they didn't investigate its histopathological effects on knee cartilage and synovium and they didn't know what was the level of damage that tramadol had given to the joint.

The limitation of the study was that we did not perform any surgery on the knee to produce inflammation. The aim of this study was to investigate the histopathologic effects of tramadol rather than to investigate its anti-inflammatory or antinociceptive effects. Further studies may be planned with longer follow up interval of the rats' cartilage.

Considering that majority of the patients undergoing arthroscopic surgery for diagnostic or therapeutic purposes are young and have long life expectancy, drug-induced joint damage in these patients can cause poor life quality.

We can conclude that intra articular tramadol for postoperative analgesia should be used with caution considering it can cause inflammation in early phases and fibrosis in late phases. Tramadol which is still administered intra articularly needs more experimental and clinical studies to highlight the potential harmful effects on articular and cartilage tissues.

\section{Acknowledgement}

We would like to thank to Prof. Esin Asan from histology department for her contribution to the examination of the tissue samples.

Declaration of Conflicting Interests: No conflict of interest of any author exists.
The study was carried out in animal research laboratory in Hacettepe University Faculty of Medicine.

\section{REFERENCES}

1. McLoughlin C, McKinney MS, Fee J, et al. Diclofenac for day-care arthroscopy surgery: comparison with a standard opioid therapy. Br J Anaesth 1990;65:620623.

2. Calmet J, Esteve C, Boada S, et al. Analgesic effect of intra articular ketorolac in knee arthroscopy: Comparison of morphine and bupivacaine. Knee Surg Sports Traumatol Arthrosc 2004;12:552-555.

3. Badner $\mathrm{NH}$, Bourne RB, Rorabeck $\mathrm{CH}$, et al. Intra articular injection of bupivacaine in knee-replacement operations. Results of use for analgesia and for preemptive blockade. J Bone Surg 1996;78:734-738.

4. Moiniche S, Mikkelsen S, Wetterslev J, et al. A systematic review of intra articular local anesthesia for postoperative pain relief after arthroscopic knee surgery. Reg Anesth Pain Med 1999;24:430-437.

5. Convery PN, Milligan KR, Ouinn P, et al. Low-dose intra articular ketorolac for pain relief following arthroscopy of the knee joint. Anaesthesia 1998;53:1125-1129.

6. Tuncer B, Babacan CA, Arslan M. The pre-emptive analgesic effect of intra articular bupivacaine in arthroscopic knee surgery. Acta Anaesthesiol Scand 2005;49:1373-1377.

7. Reuben SS, Connelly NR. Postoperative analgesia for outpatient arthroscopic knee surgery with intra articular bupivacaine and ketorolac. Anesth Analg 1995;80:1154-1157.

8. Rosseland LA, Stubhaug A, Skoglund A, et al. Intra articular morphine for pain relief after knee arthroscopy. Acta Anaesthesiol Scand 1999;43:252-257.

9. Saricaoglu F, Dal D, Atilla P, et al. Effect of intra articular injection of lornoxicam on the articular cartilage \& synovium in rat. Indian J Med Res 2008;127:367-370.

10. Denti M, Randelli P, Bigoni M, et al. Pre and postoperative intra articular analgesia for arthroscopic surgery of the knee and arthroscopy assisted anterior cruiciate ligament reconstruction. A double-blind randomized, prospective study. Knee Surg Sports Traumatol Arthrosc 1997;5:206-212.

11. Irwin MG, Cheung KMC, Nicholls JM, et al. Intra articular injection of ketorolac in the rat knee-joint: Effect on articular cartilage and synovium. Br J Anaesth 1998;80:837-839.

12. Fujii K, Tajiri K, Kajiwara T, et al. Effects of NSAID on collagen and proteoglycan synthesis of cultured chondrocytes. Br J Rheumatol Suppl 1989;18:28-31.

13. Romsing J, Moiniche S, Ostergaard D, et al. Local infiltration with NSAIDs for postoperative analgesia: Evidence for a peripheral analgesic action. Acta Anaesthesiol Scand 2000:44:672-683.

14. Kayhan Z. Klinik Anestezi. Logos Yayıncılık, Genişletilmiş üçüncü baskı, Ankara, 2004,p.106-107. 
15. Alagöl A, Çalpur OU, Kaya G, et al. The use of intra articular tramadol for postoperative analgesia after arthroscopic knee surgery: a comparison of different intra articular and intravenous doses. Knee Surg Sports Traumatol Arthrosc 2004;12:184-188.

16. Likar R, Masthiaschitz K, Burtscher M, et al. Randomized-doubled-blind, comparative study of morphine and tramadol administered intraarticulary for postoperative analgesia following arthroscopic surgery. Clin Drug Invest 1995;10:10-17.

17. Garlicki J, Dorazil-Dudzik M, Wordliczek J, et al. Effect of intraarticular tramadol administration in the rat model of knee joint inflammation. Pharmacological Reports 2006;58:672-679.

18. Rahmat A. Fatahian Dehkordi RAF, Bigham-Sadegh $A$, Vajd N. The effects of intra-articular tramadol ad- ministration on histopathological indices in rat knee joint. Veterinarski Arhiv 2014;84:667-676.

19. Zimmermann M: Ethical guidelines for investigations of experimental pain in conscious animals. Pain 1983;16:109-110.

20. David MJ, Vignon E, Peschard MJ, et al. Effect of NSAIDs on glycosiltransferase activity from human osteoarthritic cartilage. Br J Rheumatol 1992;31:13-17.

21. Ozyuvacı H, Bilgic B, Ozyuvacı $E$, et al. Intra articular injection of tenoxicam in rats: assessment of the local effects on the articular cartilage and synovium. J Int Med Res 2004;32:312-316.

22. Balabanova RM, Fedina TP, Tsurko VV, et al. Dynamic changes in synovitis activity after intra articular administration of xefocam in patients with rheumatoid arthritis (according to clinical and device examinations). Ter Arkh 2003;75:33-35. 